Acta vet. scand. $1961,2,32-59$.

From the Department of General Pathology and Pathological Anatomy and the Department of Physiology, Endocrinology and Bloodgrouping, The Royal Veterinary and Agricultural College, Copenhagen.

\title{
THE TERATOGENIC EFFECT OF VITAMIN A DEFICIENCY IN PIGS
}

By

\author{
Birthe Palludan
}

At the beginning of the present century it was generally believed that congenital malformations in man and animals were mainly caused by hereditary factors and that environmental factors were relatively unimportant in this connection.

A new era began in the thirties when, for the first time, congenital nutritional malformations due to inadequate nutrition were demonstrated by Hale in 1933, in connection with his investigations on vitamin A deficiency in pregnant sows. He demonstrated that sows entirely depleted of vitamin A during the first month of pregnancy, but later receiving sufficient amount of this as cod-liver oil, gave birth to piglets with various malformations, the most conspicuous of which were anophthalmia and microphthalmia. Other malformations, such as "excessive ears", cleft lip, cleft palate, subcutaneous cysts and malplaced kidneys were common. In later experiments Hale (1935) proved that the malformations observed were not hereditary in character, for the progeny from boars of the first experiment, when mated with appropriately fed gilts, was entirely normal. Again, when one of these blind boars was mated with a blind sow from the same litter and both were fed normally, the progeny showed no indication of blindness.

Although comprehensive experiments, such as Hale's have later been made with rats, experiments with pigs have been relatively few. However, without exception, they have confirmed Hale's results.

Schoop (1955) in investigations on vitamin A deficiency in pregnant sows, found resorption and mumification of fetuses and 
malformations such as microphthalmia and cleft palate. Bendixen (1944) in addition to microphthalmia, found malformation of the heart and subnormal development of the female genital organs. Goodwin and Jennings (1958) demonstrated eye deformities together with pronounced oedema in newborn vitamin A deficient piglets, as well as various degrees of malformation of the kidneys and histological changes of epithelial surfaces, such as proliferation and vacuolation.

\section{AUTHOR'S INVESTIGATIONS}

The experiments described in the following were made in order to study the utilization by pigs of perorally and parenterally administered vitamin $A$, the transfer of this vitamin from the sow to the fetuses via placenta, the importance of the vitamin A content of colostrum for suckling piglets and the effect of vitamin A deficiency on embryonic development. The investigations proved among other matters that gilts, which, until the beginning of the first pregnancy were fed a vitamin sufficient diet, but from then on received no vitamin $A$, were able to complete two pregnancies normally before any vitamin-A deficiency symptoms were manifest. If immediately after weaning, piglets were fed a ration insufficient in vitamin $A$, they were unable to complete a normal pregnancy period and therefore gave birth to malformed nonviable piglets. The diet given, as already stated by $H$ jarde et al. (1961) consisted of barley, dried skimmed milk and mineral salt mixture. It contained a supply of $200-1.000$ I.U. D-vitamin per day.

The first investigations comprised three gilts, litter mates numbers 3, 4 and 7. They were purchased when two months old and then fed a vitamin A free diet. The vitamin A content in the liver, calculated from analyses of liver biopsies, decreased constantly. When the pigs were killed no vitamin A could be detected in their livers cf. Table 1 . Gilts numbers 3 and 4 completed pregnancy normally. Of nine malformed pigs in litter 3 , only one was alive at birth and died immediately after. In litter 4, which comprised five malformed piglets, one was a still-born piglet and the other four litter mates died after a few minutes. Already two months after breeding, this last gilt, number 7, showed symptoms of ataxia and incoordination in connection with lordoscoliosis. As the condition became steadily worse and as the gilt was unable to get up when the date for farrowing had passed, it was killed. The uterus contained six living, but malformed piglets. All died after a few minutes (Fig. 1). 
The following series of investigations comprised two gilts, designated $111 / 27$ and $111 / 28$. Their mother, sow number 111 , had been kept on a vitamin A free ration from the beginning of pregnancy. As a result the piglets, even at weaning, had had very small liver deposits. The gilts were kept on a ration deficient in vitamin A during growth and pregnancy. 28 and 53 days after breeding, gilts 27 and 28 respectively were injected with 500.000 I.U. vitamin A in aqueous dispersion and they completed pregnancy normally. Gilt 27 farrowed a litter of six malformed piglets. Two of these were still-born, the remaining four, very weak. These latter could not suckle the sow, were unable to move normally and showed symptoms of paresis and paralysis. Three of the four died within the first twenty-four hours after birth, the remaining died when three weeks old. Gilt no. 28 farrowed a litter of eight living but malformed piglets. These showed the same clinical symptoms as the pigs in litter 27, though hardly so strongly marked. Four of the piglets died in the course of the first ten days. Of the remaining four, the last was killed at an age of two months as it was moribund.

Sows 111 and 112 were both kept on a vitamin A free diet from the beginning of the first pregnancy. Sow 111 completed two normal pregnancies but sow 112 miscarried once and then farrowed a normal litter. After the second pregnancy, sow 112 showed symptoms of vitamin A deficiency, unstable appetite, trembling and incoordination. Therefore in order to ensure a third pregnancy, sows 111 and 112 were given 33 and 31 days after breeding, respectively, 500.000 I.U. vitamin $A$ in aqueous dispersion intramuscularly. As sow 112 continued to show the above-named signs of vitamin-A deficiency, 61 days after breeding it was given a further injection of 500.000 I.U. vitamin A. After this both sows completed pregnancy normally and each farrowed 15 blind piglets. Of these 30 piglets 7 died the first day, the remainder, though weak, continued to live.

The last gilts to be mentioned are $111 / 47$ and $111 / 54$, both derived from the second litter of sow 111. At birth these piglets, by analyses made of their litter mates, had no vitamin A content whatsoever in the liver. As it was presumed that the gilts would be unable to complete a pregnancy, gilt 47 was twice given intramuscular injection of 500.000 I.U. vitamin $A$ in oil, 29 and 43 days after breeding. Gilt 54 was given 500.000 I.U. vitamin A 36 days after breeding. Both gilts completed pregnancy normally and the litters comprised respectively 15 and 12 malformed piglets. Of these some were stillborn and the others not viable. All the piglets were moribund and died or were killed within the two first days after birth.

On 3 piglets from each of the 9 litters an autopsy was performed within 24 hours after birth. Material for histological investigations was taken from the following tissues: skin, including mammary gland, turbinate bones, humerus, rib junction, middle ear, eye, cerebrum, cerebellum, medulla oblongata, cervical and lumbar enlargement of spinal cord, tibial nerve, brachial plexus, semitendinosus and semi- 


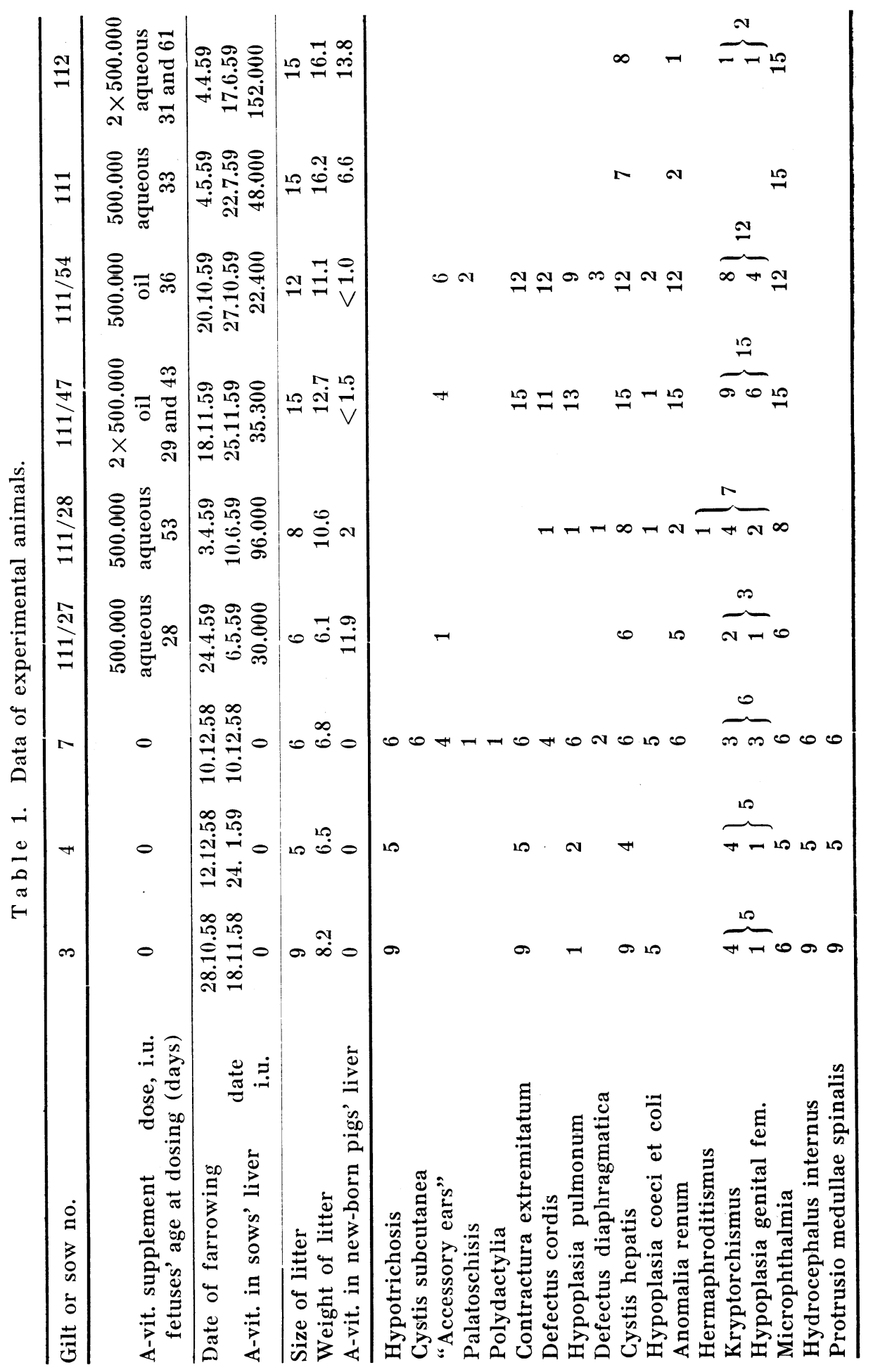


membranosus muscle, tongue, salivary glands, posterior superficial cervical and prefemoral lymph glands, oesophagus, stomach, small and large intestines, trachea, lung, heart, spleen, liver, gall-bladder, pancreas, kidney, bladder, testicle, ovary, uterus, cervix, vagina, urethra, pituitary gland, thyroid gland, thymus and adrenal glands.

The material was fixed either in 4 per cent formaldehyd solution or in absolute alcohol and embedded in paraffin. The following staining techniques were used: v. Gieson-Hansen, Hematoxylin-Eosin, Sudan III, Best-glycogen, Loyez (myelin-sheaths), Romanes (neurofibrils) and Einarson (nucleic acids).

The malformations found by autopsy are listed schematically in Table 1. It appears that microphthalmia was the most frequent malformation present in all the pigs except three from litter 3 . With the exception of microphthalmia in litters 27, 28, 111 and 112, characteristic malformations of the urogenital system and liver only were found. In the other litters numerous malformations were common. Pigs from litters 3, 4 and 7 differ from pigs in litters 47 and 54 by distinct malformations in the central nervous system, while in pigs in the other litters there were rather similar changes in the development of the heart and of the urogenital system.

Table 1 shows that the number and weight of the pigs in the litters varied greatly. There were also great variations in the size of the piglets in the single litters.

Skin. In contrast to the other litters, it was characteristic of the pigs in litters 3, 4 and 7 that hair growth was sparse (Fig. 1.). After birth amniotic flakes very difficult to remove from the skin were observed. Only under close inspection could very fine, short hair be seen. The piglets of these litters seemed plumper than normal and the bellies were slightly distended. All the piglets of litter 7 had large subcutaneous cysts in neck, loin and belly regions. These cysts contained a clear, gelatinous fluid. A similar fluid could be pressed from the subcutaneous tissues and measured up to $1 \mathrm{~cm}$. in thickness. The thoracic cavity, pericardium and abdominal cavity contained fluid - both serofibrinous and mixed with blood.

In histological investigations of skin, a normal keratinization of epithelium was found. Marked oedema was observed in subcutis, corresponding to the macroscopic picture. The subcutaneous tissue greatly resembled primitive mesenchymal tissue; it was relatively rich in cells and collagen fibres were few and scattered. The many lymphatic vessels were strongly dilated. 


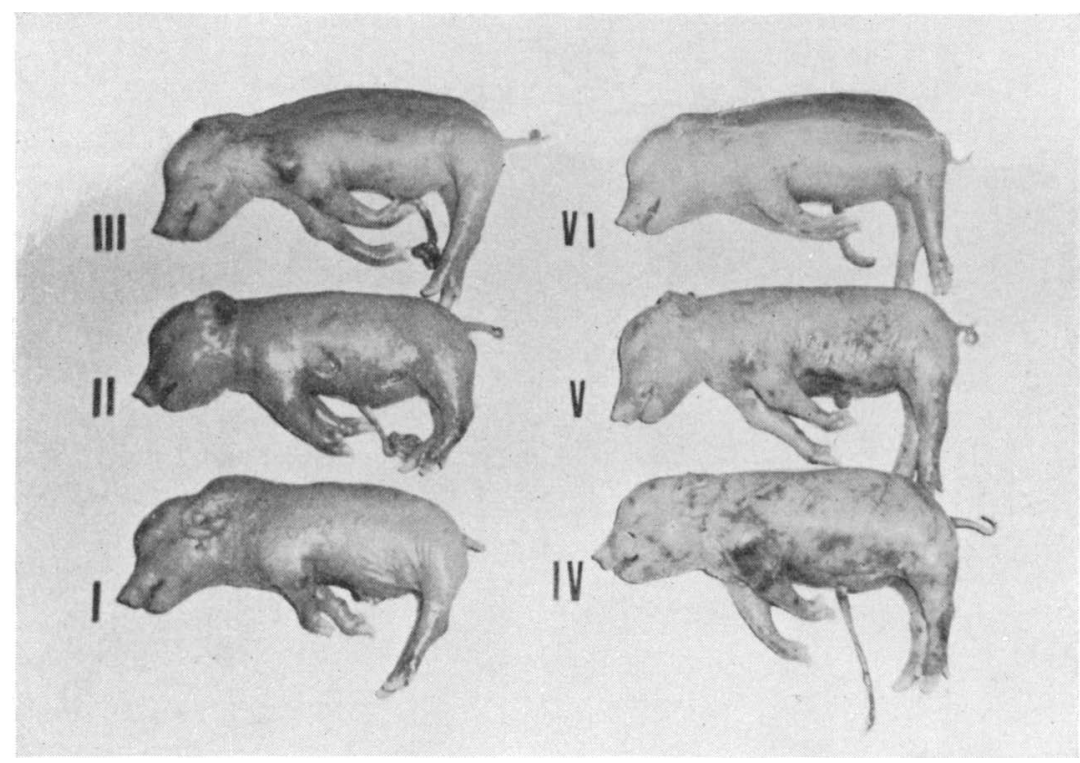

Fig. 1. Litter no. 7. The following malformations are observed: microphthalmia, hypotrichosis, contracture of the limbs and general oedema.

Ears. In some piglets were observed so-called "excessive ears", placed caudally to the normal ears. These "excessive ears" were shaped quite like normal ear laps though considerably smaller. They consisted of skin-covered cartilage, which, microscopically, was seen to be differentiated as elastic cartilage.

Limbs. In one pig polydactylism was observed as a doubling of the second metacarpus of the left foreleg. All the pigs of litters $3,4,7$, as well as those of 47 and 54 showed pronounced contractions of the forelegs. These were very bent and impossible to straighten by passive movements. The hindlegs of the same pigs were abnormally stretched which made them appear longer than the forelegs. The articular surfaces of the pigs from litter 47 and 54 were normal, this was not the case in pigs from litters 3,4 and 7 . When the joints were opened, these were found abnormal with uneven depressions and corresponding protrusions in the cartilage.

Macroscopically the musculature of the limbs was very light in colour. By histological examination they proved to be very poorly developed and degenerative changes were found with small fat droplets in the skeletal muscle fibers. Microscopy of the 


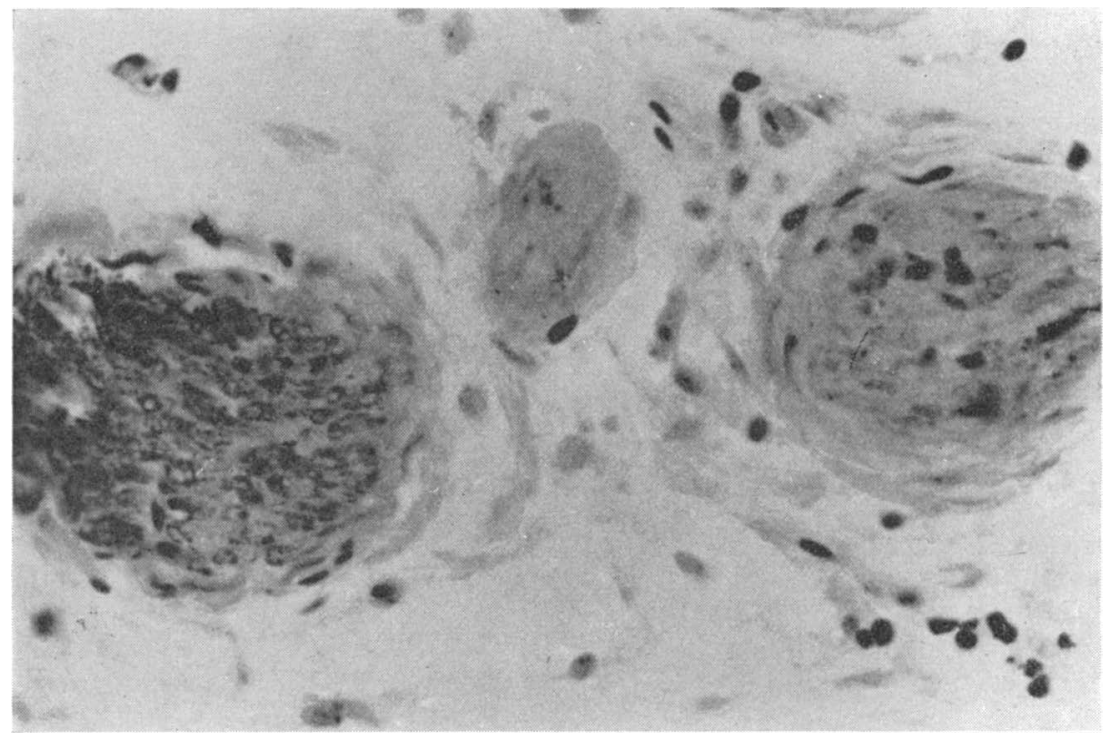

F i g. 2. Nerve section, brachial plexus, pig. no. 7II. At the left normal myelin sheaths (black) at the right demyelinization.

Loyez (magn. appr. $500 \times$ ).

brachial plexus and the radial nerve also revealed pronounced degenerative changes with partial loss of axis cylinders and myelin sheaths (Fig. 2). The calibration of the axis cylinders varied and there was poor staining affinity. Surrounding the fragments of the myelin sheaths were several macrophages containing fat droplets.

Palate. In 3 of the pigs uniform malformations of the palate were found with a characteristic posterior cleft palate.

Heart. Malformations of the heart were found in some of the pigs from litter 7 , but cardiac anomalies were very pronounced in pigs from litters 47 and 54 (cf. Table). Generally the hearts were slightly enlarged as the cardiac muscle was spongy and trabeculated. A characteristic malformation found in nearly all the above-mentioned piglets, consisted of a persistent interventricular foramen varying in diameter from $1-3 \mathrm{~mm}$. In most cases malformations were observed in the walls of the atrium. In two of the pigs these malformations comprised total absence of the interatricular septum, cor triloculare biventriculosum, in other pigs foramen interatriculare differed somewhat in size.

The aortic-arch system was also the seat of malformations. 


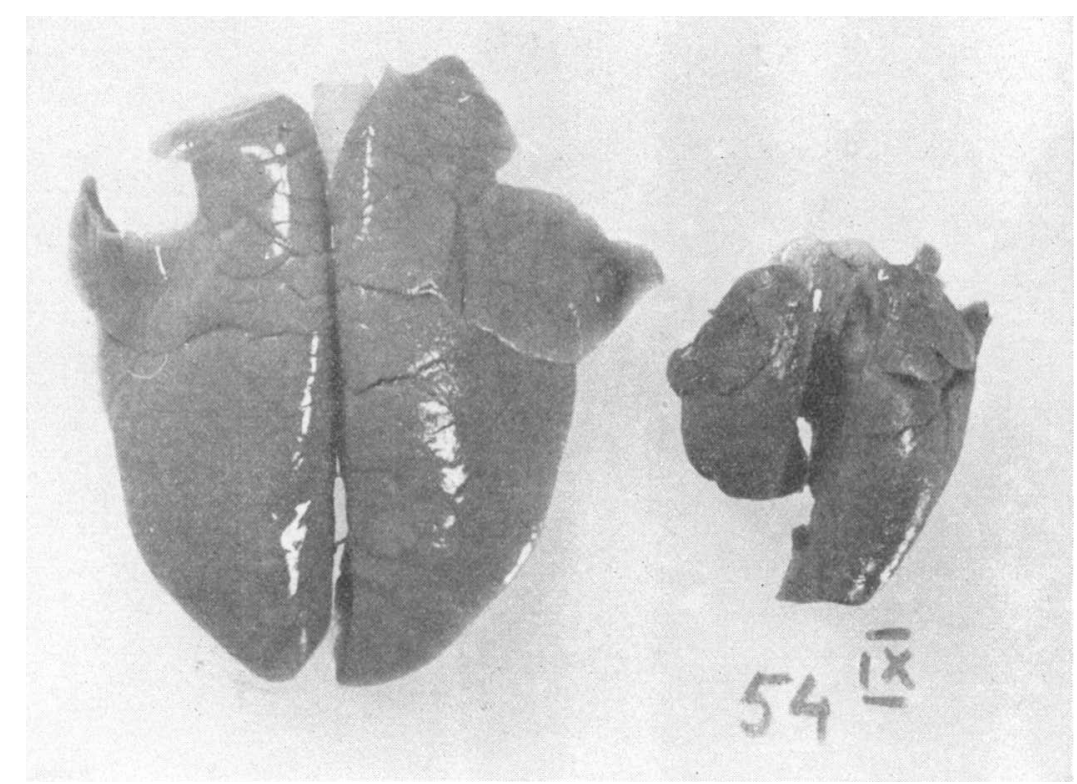

F i g. 3. Lungs from normal piglet sacrificed immediately after birth and lungs from pig. no. 54Ix. Hypoplasia most pronounced in the left lung, abnormal lobulation.

In two of the pigs a truncus arteriosus issued from both of the ventricles, truncus arteriosus communis; more frequently there was a decided disproportion between the size of the pulmonary trunk and aorta near the semilunar valves. The circumference of the pulmonary orifice varied from 11 to $17 \mathrm{~mm}$., the periphery of the aortic orifice measured from 3.5 to $7 \mathrm{~mm}$. Similarly, the diameter of the ascending aorta was considerably less than the diameter of the pulmonary artery. Ductus arteriosus (Botalli) persistens of considerable size was frequently observed.

Microscopic examination of the heart showed that at birth the myocardium in these pigs was less well-developed than normal. Around the inter-ventricular malformations and placed subaortally in the pigs with malformations of the main blood trunks, primitive, poorly differentiated connective tissue was found subendothelially.

Lungs. In the pigs of litters 3, 4 and 7 and to a greater extent in those of litters 47 and 54, lung malformations were found and especially in the left lung (Fig. 3). Here the diaphragmatic lobe was definitely smaller than the corresponding right lobe. The 


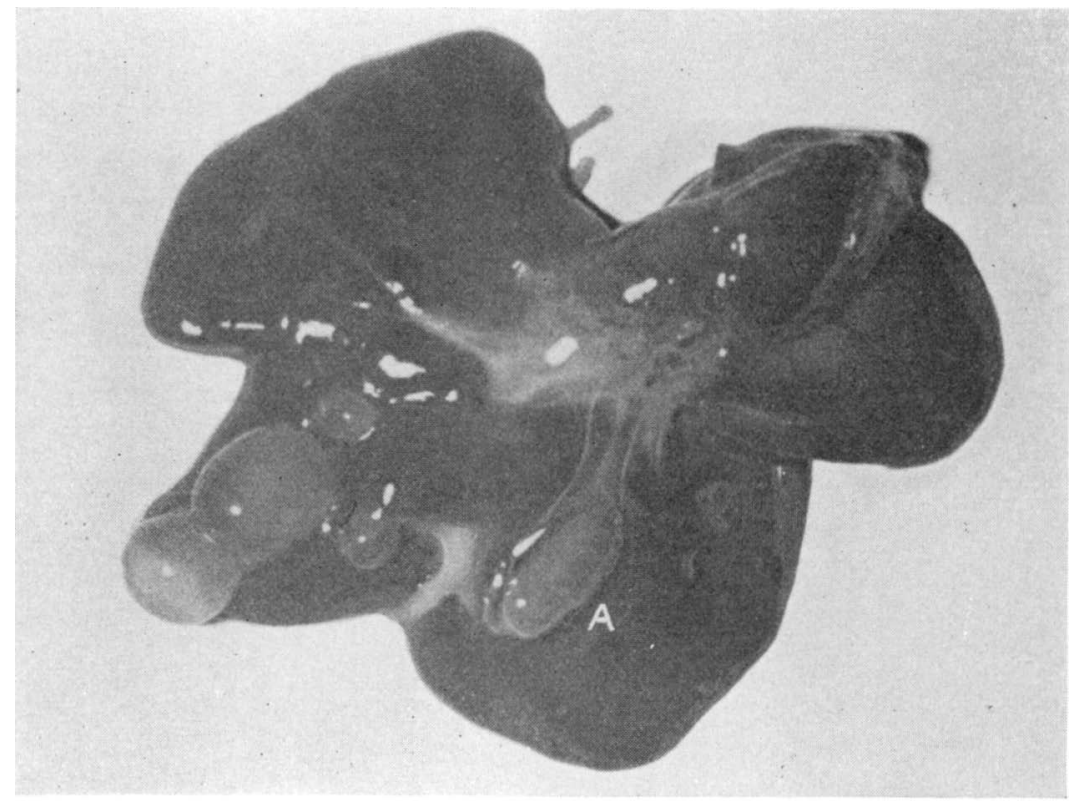

F i g. 4. Liver, pig no. 28II. Several cysts are visible. A: gall-bladder.

apical and cardiac lobes were either very small and rudimentary or totally lacking. Abnormal lobulation was present most frequently as subdivision of the single lobes, but it occasionally appeared as incomplete separation of the lobes.

Except for slight interlobular oedema, no characteristic histological changes in the lungs were observed. In a few pigs in litters 3,4 and 7 , a slight vacuolization of the bronchial epithelium was found, but in no case was there any indication of metaplasia.

Diaphragm. Six of the pigs showed defective closure of the diaphragm, most often with a slit-like opening in the tendinous center through which part of the left central lobe of the liver protruded into the thoracic cavity, while in a few cases it was part of the stomach.

Liver. In the majority of the pigs examined the liver contained several cysts varying in size from those barely visible, to others the size of a hazel nut (Fig. 4). These cysts contained a fluid which varied from serous to hemorrhagic. The color of the liver also varied greatly. It was mottled with yellowish patches scattered among bluish brown patches. The content of the gallbladder was highly viscous. 
Histological examination of liver revealed macroscopically determinable "cysts" located in some cases sublobularily, in other cases in the triades or centroacinally. The walls consisted of an endothelium surrounded by a rather distinct muscular coat and adventitious connective tissue. This formation suggested pronounced dilatation of both interlobular, central and sublobular veins. The liver had a distinctive characteristic fetal shape, the limits of the single lobules could hardly be distinguished and blood formation still took place to a very large extent.
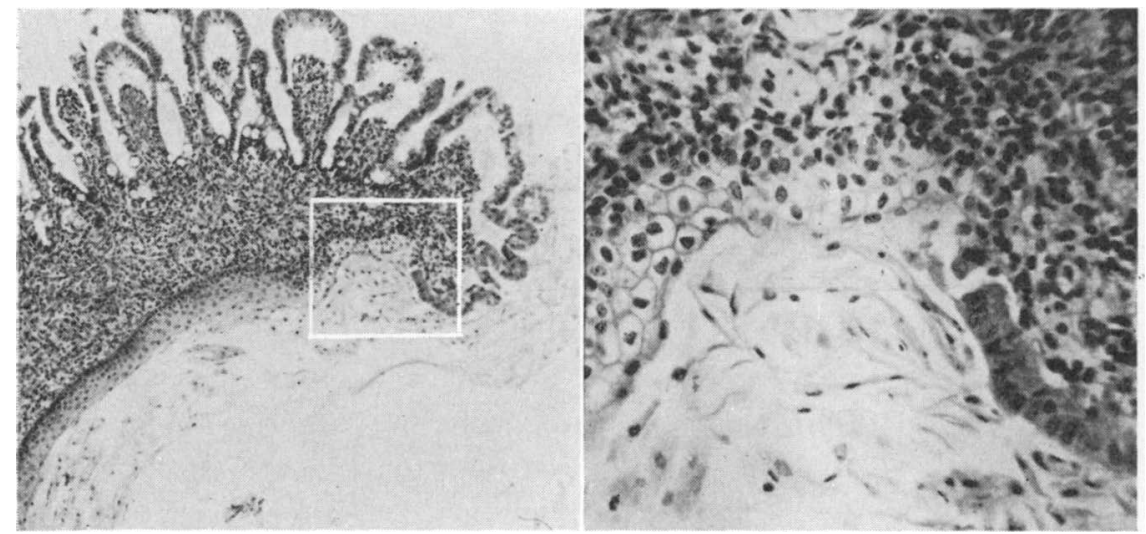

F ig. 5. Duodenum, pig no. 7II. In the upper part at the left villi are seen (magn. appr. $60 \times$ ). The part framed at the left is shown in higher magnification at the right. The columnar epithelium changes to stratified squamous epithelium. (magn. appr. $500 \times$ ).

Gastro-intestinal tract. Stomach and small intestines were practically empty; in the coecum and in colon was a very viscous mass of which the surface was thickly covered with mucus.

No macroscopic malformations were found in stomach or small intestine; in coecum and colon of several pigs from litters $3,7,47$ and 54 were rather pronounced changes. A pronounced hypoplasia was apparent, as coecum was often not more than $1 \frac{1}{2} \mathrm{~cm}$. in length and $3 \mathrm{~mm}$. in diameter. Instead of the normally developed colon spiral, the spiral cords of the colon in these pigs were so arranged that only in the terminal part was there indication of normal spiral formation. No longitudinal muscular bands and sacculations were observed either in coecum or colon.

Histological changes in the gastro-intestinal tract were noted 
mostly in pigs from litters 3,4 and 7. Here poor development of glands was found in fundus of stomach and in all parts of the intestines. Only in a single case was there found metaplasia of the mucous membranes of the intestines. This was in a pig from litter 7. Histological examination showed a change in epithelium of duodenum covering a space of $3 \mathrm{sq}$. mm. (Fig. 5). The columnar epithelium changed into stratified keratinizing epithelium. No glands whatsoever were found and the submucous layer consisted solely of undifferentiated mesenchymal cells.

Kidneys. As already stated, malformations of the kidneys were frequent in the pigs from the litters investigated. The most pronounced anomalies were found in litters 47 and 54. These malformations can be grouped in two categories, which in most cases appear simultaneously. One category comprises malplacement of the kidneys, the other, their actual shape and development.

In these pigs the characteristic position of one or both kidneys was at the cranial entrance of the pelvic cavity, or in the pelvic cavity. The kidneys were often displaced in respect to each other, one kidney, for instance, could be located opposite the fourth or fifth lumbar vertebra, while the other was located opposite the foremost sacral vertebra. Furthermore, the transversal distance between the kidneys varied as they were seldom normally paravertebral, but were medially displaced so that the capsules of the kidneys were adherent or, in the most malformed cases, had fused, whereby a so-called "horse-shoe kidney" was formed. The more caudally the kidneys were placed, the more pronounced were the changes in the kidneys themselves. In no cases were both kidneys of these pigs of the same size. Usually one kidney was appreciably larger than normal (f. inst. $3 \times 2 \times 2$ cm.) while the other was abnormally small (f. inst. $1 \frac{1}{2} \times 1 / 2 \times 1 / 2$ cm.). The shape was far from normal, triangular or quadrangular with irregular contour. The surface was rough, in some cases there was external lobation of the kidney. After decapsulation the color of the kidney was grayish and on the fresh cut were stripes of connective tissue which stretched through the cortex. In the cortex were several cysts with a clear serous content. The boundary between cortex and medulla was indistinct and the medulla often seemed to be hypoplastic. In a few pigs there was. dilatation of the pelvis due to hydronephrosis. 


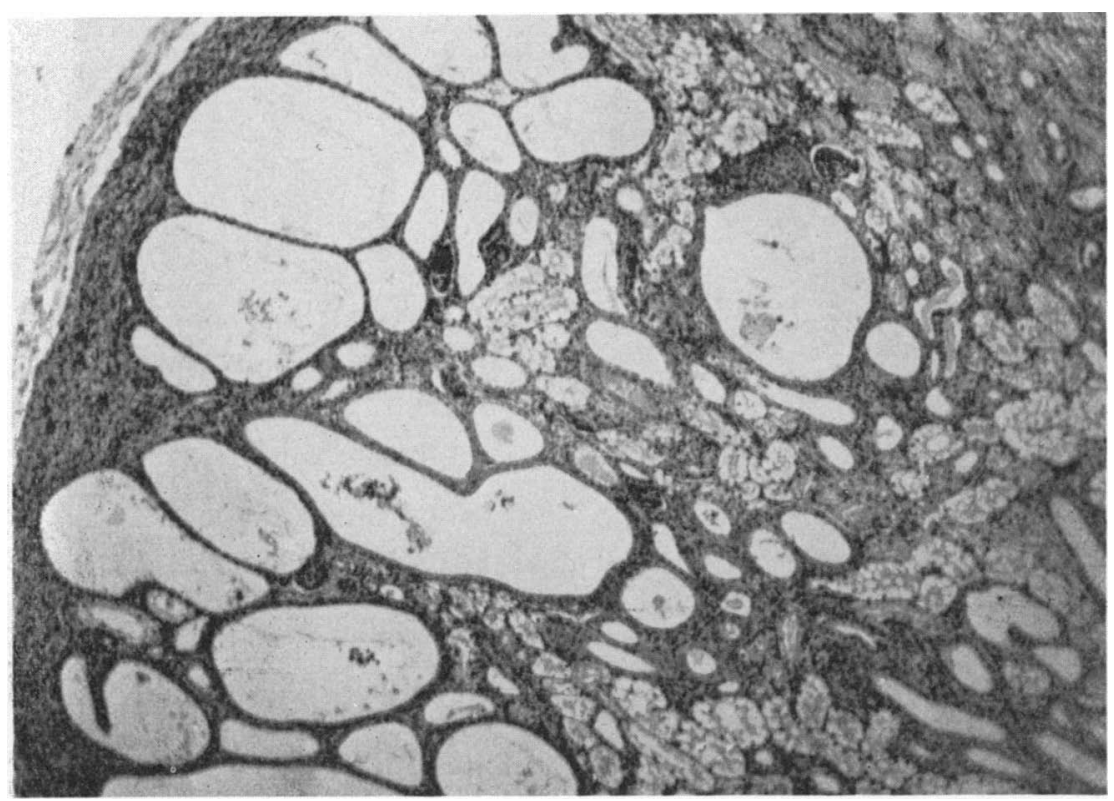

F i g. 6. Kidney, pig no. 7III. Subcapsularly undifferentiated blastema. In the cortex several dilated tubuli. Hematoxylin-Eosin.

(magn. appr. $60 \times)$.

In malformed kidneys, hilus had a placement far from normal. It was situated ventromedial or ventral, instead of medial. In several pigs there was dilatation of ureter, hydro-ureter, but there was usually connection between ureter and vesica and as a rule ureter was only $1-2 \mathrm{~cm}$. long.

Histology. The cortex was relatively broad, the medulla was narrow, or totally lacking. However the cortex had not reached the stage of development which is normal at birth. Subcapsularly placed, was a very broad zone composed of an undifferentiated blastema rich in cells. In the cortex were many cyst-like formations composed of greatly dilated tubuli (Fig. 6). These cysts were generally grouped in patches. Dilatation of Bowman's capsules were seldom observed. The glomeruli in the outermost part of the cortex were poorly developed as is common in the normal newborn piglet. In place of the medulla there was an embryonic undifferentiated connective tissue.

Histologically there were no variations from the normal in the ureters and bladder, but changes in epithelium were found in vagina and especially in the male urethra. The epithelium 


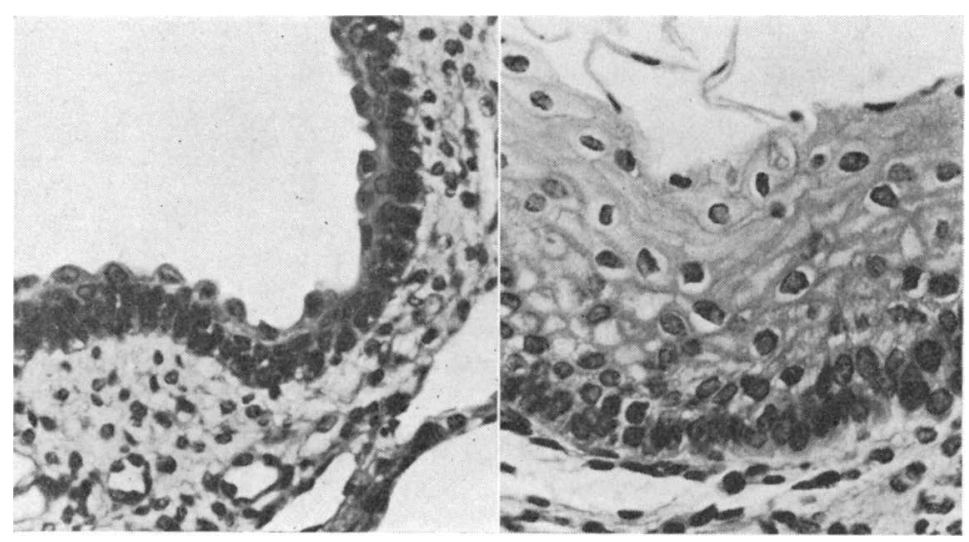

F i g. 7. Urethra from normal piglet at the left and from pig. no $3^{I}$ at the right. Keratinizing metaplasia with desquamation of epithelium is seen. (magn. appr. $500 \times$ ).

was considerably increased in thickness; besides proliferation, vacuolization and degenerative changes in cell nuclei appeared (Fig. 7).

Genital tract. The ovaries were placed more cranio-medially and dorsally than normal. In young male pigs abdominal cryptorchidism was very common. Ovaries and testes were hypoplastic. In one pig bilateral glandular hermaphroditism was observed, as the sexual glands consisted of a mixture of testicle and ovary tissue and the ductus deferens were situated parallel to the rather well developed uterus in the broad ligaments of uterus. Cervix and vagina were found normal, but clitoris was abnormally large. In male pigs rudiments of the Müllerian ducts were found and usually the most cranial parts of these were preserved. Ductus deferens was present in its full length. In the gilts numerous malformations were found in the genital organs. Though the ovaries were present in all cases, one or both oviducts were often missing. Generally the most cranial part of the horns was developed while the caudal part consisted of a thin, fibrous cord (Fig. 8). In some pigs these cords could be traced caudally to the bladder where they disappeared in the ligament so that body of uterus, cervix and vagina were lacking. In other cases, only part of the horns was lacking, and the body of uterus as well as cervix and vagina were normal.

Histological examination of ovaries and testes confirmed the macroscopic hypoplasia. In testes relatively few tubuli were found 


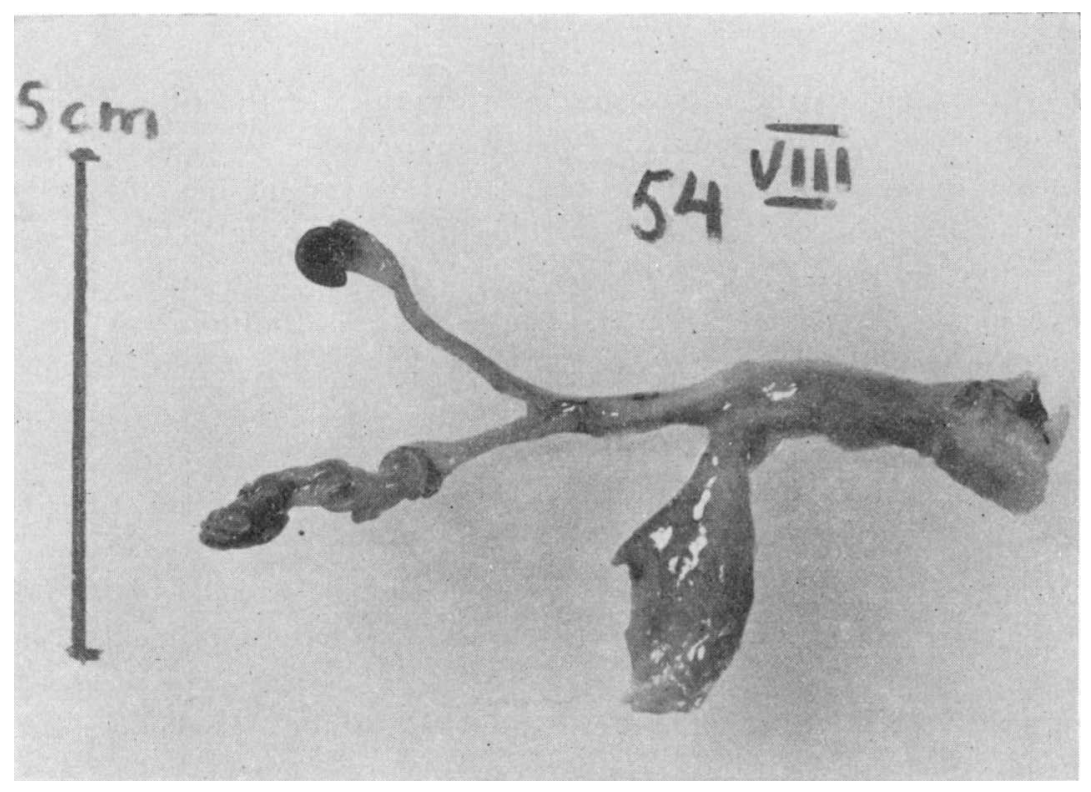

F i g. 8. Genital organs and bladder from female pig. no. 54viII. Only the most cranial part of the left uterus horn is present while the remaining part of the uterus and the cervix are lacking.

but there were many interstitial cells. In female piglets in litters 3,4 and 7 the development of the ovaries seemed to have ceased at a rather early stage as no follicles whatsoever had been formed and the largest part of the ovaries consisted of primitive connective tissue. In both ductus epididymis and ductus deferens, microscopic hypoplasia was noted in form of failing canalization. Lumen of the excretory ducts consisted of cells which were undergoing regressive changes. Epithelium was irregular multilayered and the muscular tissue primitive in development.

In pigs in which oviduct was present, it was histologically, completely normal in development. However this did not apply to uterus. As already stated the cranial part of the uterus horns was often normal, macroscopically, but histologically, metaplasia of epithelium could be demonstrated with proliferation and formation of a multi-layered epithelium with very heterogenous cell forms and degenerative changes. Myometrium was rich in cells and poorly differentiated. In the caudal part of horns which in many gilts macroscopically appeared as a "fibrous" cord, microscopic changes were found. These corresponded exactly to 
the changes described in ductus deferens with lacking canalization.

Eyes. Of all the malformations observed in the litters investigated, microphthalmia was the most frequent. It was observed in eighty-eight of the ninety-one pigs. However the degree of the changes in the eye seems not only to vary from one litter to another, but from one piglet to another in the single litter. However it may be said that on the whole, microphthalmia was most pronounced in litters 47 and 54 where in some of the pigs no disposition whatever for eyes could be observed. The general character and appearance of the eyes was as follows: The eyelids were stuck together with a brownish, fatty substance and turned inward with very distinct entropion. Bulbus oculi was considerably below normal in size and deep sunk. Occasional adherence of eye-lids and cornea was observed. In some of the pigs in litter 3 the eyes, by macroscopic examination seemed normally differentiated, but were, however slightly hypoplastic. In most of the pigs, only a slight trace of the normal eye disposition was apparent: cornea, grayish and quite opaque; iris lacking; the lens in most cases considerably smaller than normal - in a few cases, enlarged. In two of the pigs bulbus oculi was partially divided by connective tissue into two parts - each of these contained a hypoplastic lens (Fig. 11). Most often it was impossible macroscopically to distinguish the separate parts of the eyes, and bulbus oculi consisted then of several cysts with a content which varied from clear serous fluid to hemorrhagic or black-pigmented liquid. The optic nerve in all the pigs was thread like and foramen opticum measured only $1 \mathrm{~mm}$. in diameter. In a few pigs "macrophthalmia" seemed to be present instead of "microphthalmia" but also in such cases the greatly enlarged eye-ball consisted merely of large cysts with no indication of normal disposition for eyes.

The histological picture of the eyes varied as much as the macroscopical. As a characteristic example the eyes of a pig from litter 4 will be described more fully (Fig. 9). Bulbus oculi measured $5 \mathrm{~mm}$. in diameter and was nearly circular in shape. Between the eyelids were a $1 \frac{1}{2} \mathrm{~mm}$. wide fissure where it was possible to differentiate the conjunctival sacs. The conjunctival epithelium in the region corresponding normally to cornea consisted of an abnormally thick, keratinizing epithelium so that cornea was determined by placement alone. Under the keratinized 


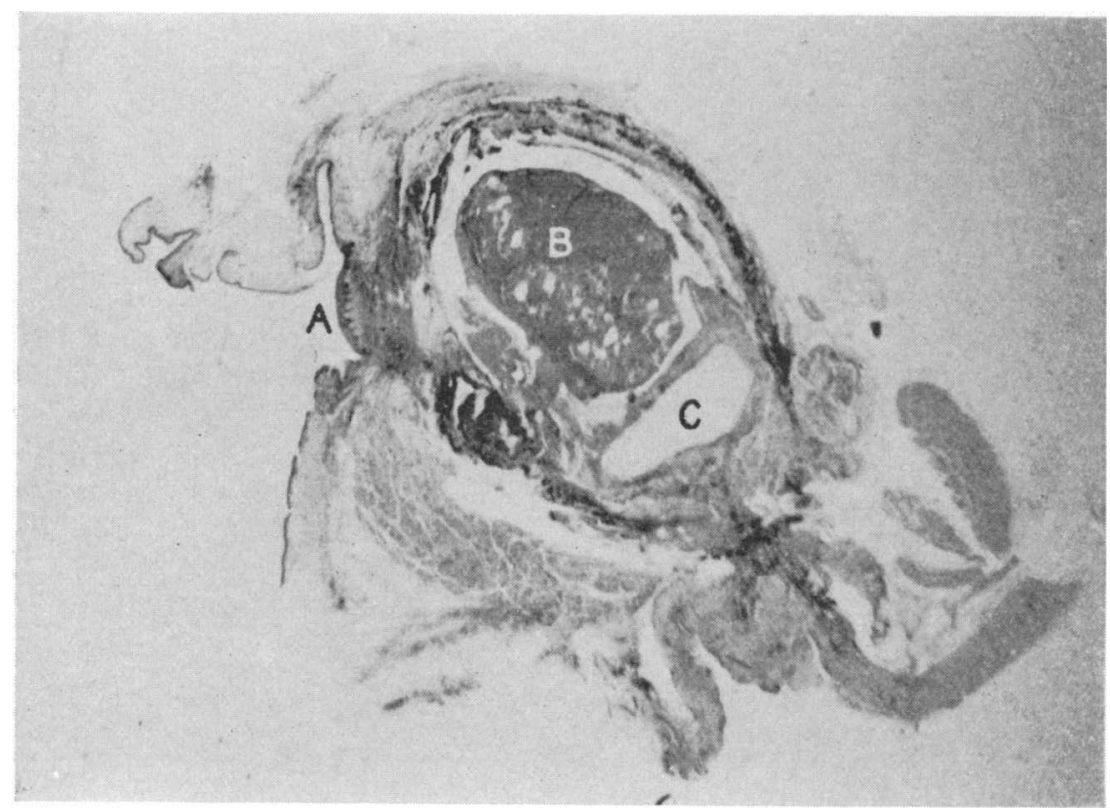

F i g. 9. Eye, pig no. 4I. A: cornea, B: lens and $\mathrm{C}$ : hyaline certilage, surrounded by connective tissue. V. Gieson-Hansen. (magn. appr. $8 \times$ ).

layer was a very fibrous, consisting of connective tissue, poor in cells. The innermost part of this layer was pigmented. Neither the anterior or posterior chamber were present, so the cornea closely adjoined lens. This was relatively large and in its entire circumference closely surrounded by elements of tissue. The surface of the lens was covered with a pigmented layer of cells within which was a narrow layer. of connective tissue with numerous capillaries. This connective tissue was limited inwardly by a cell layer surrounding the quite abnormally homogenous central portion of the lens itself. Immediately caudal to the lens where the vitreous humour might be expected was a space one third the size of the lens, composed of hyaline cartilage. Both choroidea and sclera, in so far as it was possible to localize them, formed broader layers of cells than normal. In sclera in particular was observed an extreme pigmentation. Suggestion of the layers of the retina was seen here and there, but in general there were conglomerates of nerve-like cells which united caudally in the optic nerve.

As stated, a few pigs in litter 3 had eyes, which, macroscopically seen, were nearly normal in development. However, 


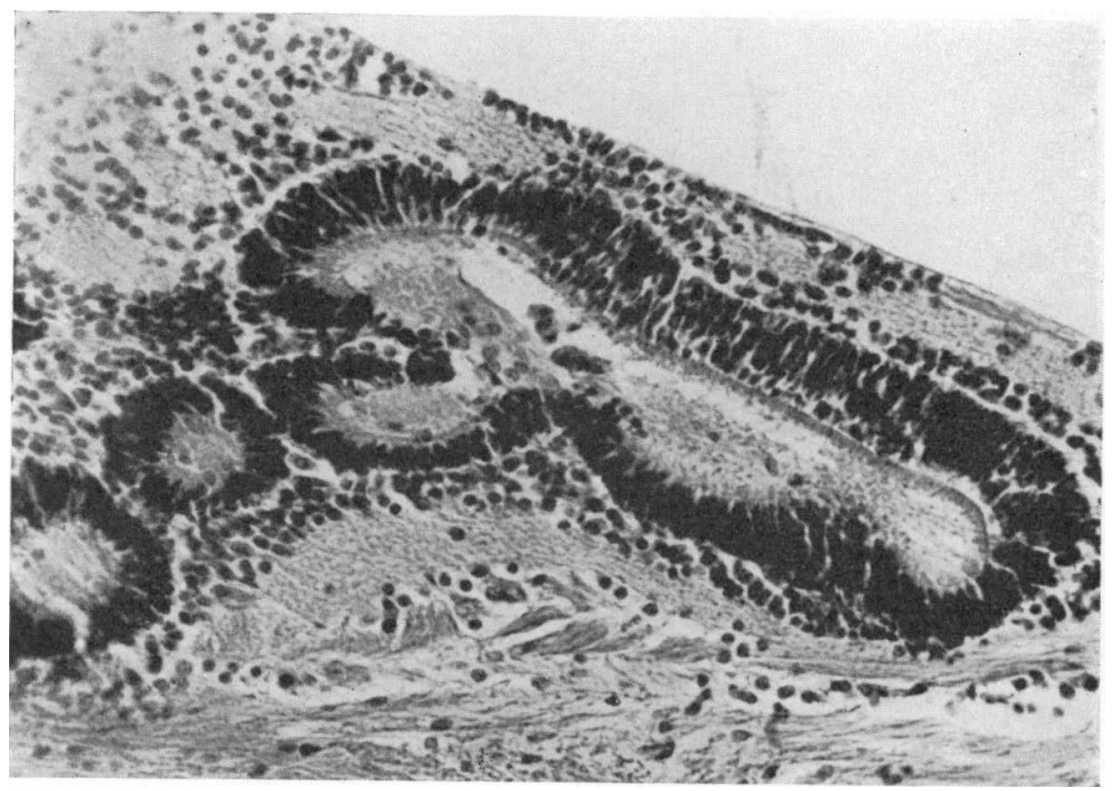

F i g. 10. Eye, pig. no. 3II. Retinal rosettes. V. Gieson-Hansen. $($ magn. appr. $250 \times)$.

here too, microscopic examination showed deviations from the normal. Retina was normal except near the optic papilla of the optic nerve where retina proliferated into corpus vitreum. In this region epithelium was abnormal forming so-called retinal rosettes which consisted of both internal and external nuclear layers surrounding lumina of different shapes (Fig. 10).

The eyes of the pigs in litter 7 were in general very poorly developed. It was impossible to identify cornea. The lens which was very small and irregular in shape, was located in subcutis, surrounded on all sides by connective tissue. In this connective tissue were numerous scattered areas of hyaline cartilage as well as pigmented and nerve tissue, retina, where the different layers were wholly undistinguishable.

In the other litters, the histological picture likewise varied. However in more of these pigs was there normal differentiation of layers in the eye. As a rule the changes, for inst. of the lens varied in character, the lens could be entirely lacking, abnormally large or small or even, as already stated, doubled (Fig. 11). The macroscopically described cysts with a serous, brown-pigmented or hemorrhagic content were microscopically found to be surrounded by a lowprismatic, pigmented epithelium. 


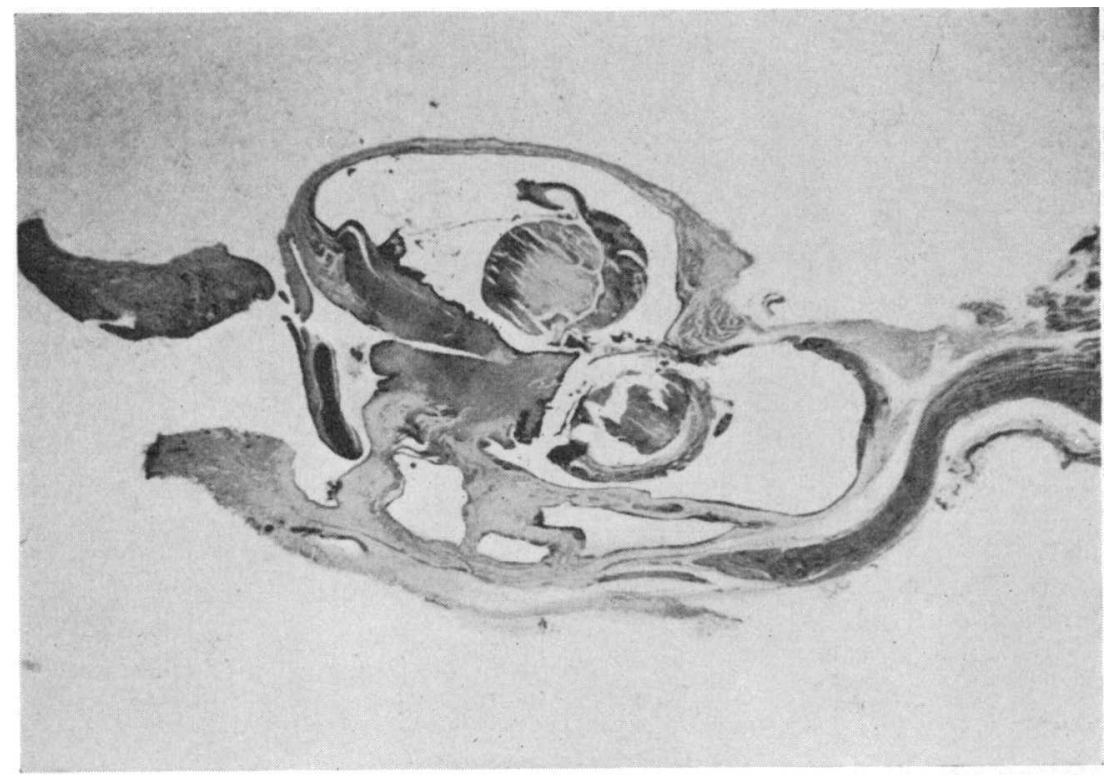

Fig. 11. Eye, pig no. 112I. Two partly separated vesicles each containing a lens. Hematoxylin-Eosin. (magn. appr. $6 \times$ ).

Central nervous system. As appears in Table 1, malformations were found in the central nervous system in all pigs from litters 3,4 and 7. Investigations of the brain showed bones of the roof of the cranium to be very thin, with large fontanelles. In contrast, the bones in the basilar part were thicker than normal (the basilar part of the occipital bone $4 \mathrm{~mm}$. thick, normal $2 \mathrm{~mm}$.). Cerebrum and cerebellum were closely surrounded by meninges and cranium. Cerebrum was more circular in form than normal (Fig. 12). Cerebral convolutions were flattened with sulci and gyri lying on the same plane. An incision in the brain revealed distinct dilatation of first, second and third ventricle, no dilatation of the aqueduct of Sylvius nor of the fourth ventricle. The lateral ventricles contained profuse serous liquid. Both the gray and especially the white matter were appreciably narrower than normal.

All the pigs of these litters also had characteristic malformations of the spinal cord. Corresponding to what has been described in the brain, the spinal cord was very closely surrounded by meninges and the vertebral column. On both sides of the spinal cord, and particularly pronounced in the lumbal region, de- 


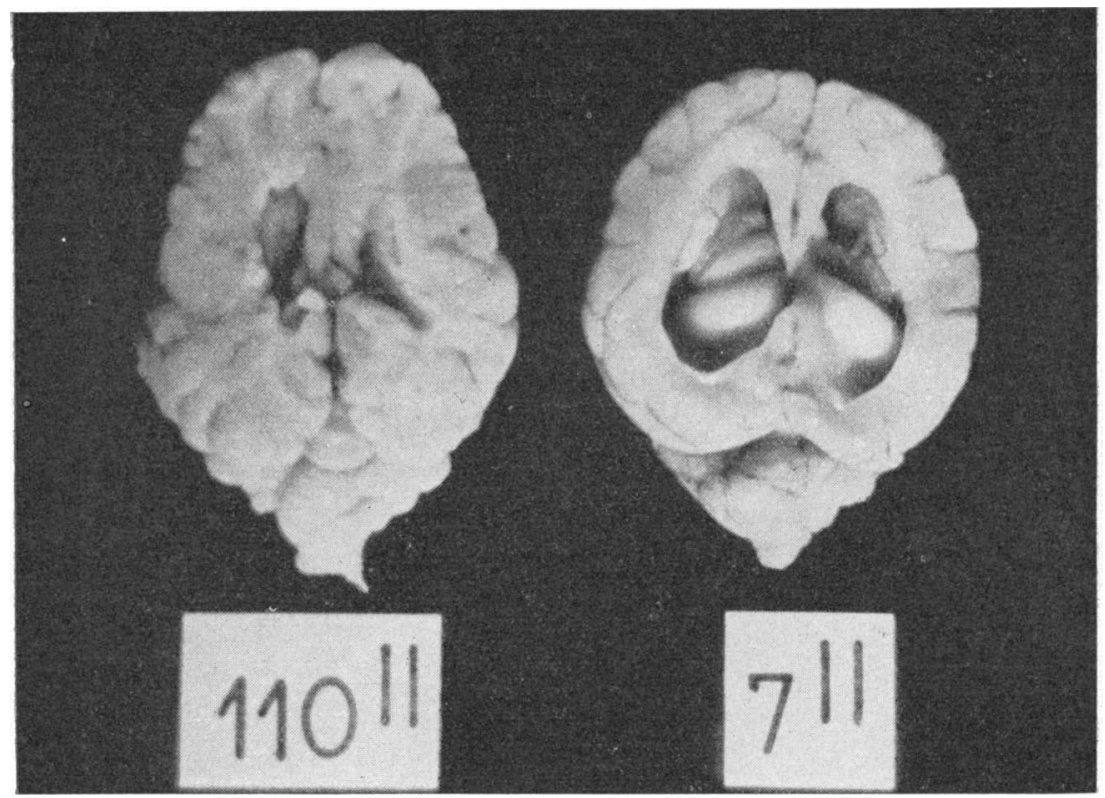

Fig. 12. Brain from normal newborn piglet at the left and from pig no. 7II at the right. Altered shape of the brain, dilatation of the lateral ventricles, the gray and especially the white matter thinner than normal.

formities were found located medially to the spinal ganglions at all the nerve roots (Fig. 13). These deformities appeared to be protrusions of the spinal cord.

Histological examination of the brain revealed pronounced oedema in both the white and the gray matter. The nerve tissue was less well-developed than normal, the nerve cells varied greatly in shape, in size and in staining affinity. Some of the cells were chromophobic, some cromophilic. No reactive changes with proliferation of the glia were observed. The protrusions of the spinal cord, already mentioned, consisted of nerve-roots which seemed to have been pressed into the intervertebral foramina. Mechanical injury extended to the spinal canal, the shape of which was altered. Ganglion cells were severely damaged; often necrotic with malformed nuclei and cytoplasma. At the bends and compressions of the nerve tissue injuries to the neurofibrils and demyelination were found. The closely encompassing meninges were thickened, poor in cells and contained many collagenous fibrils. 


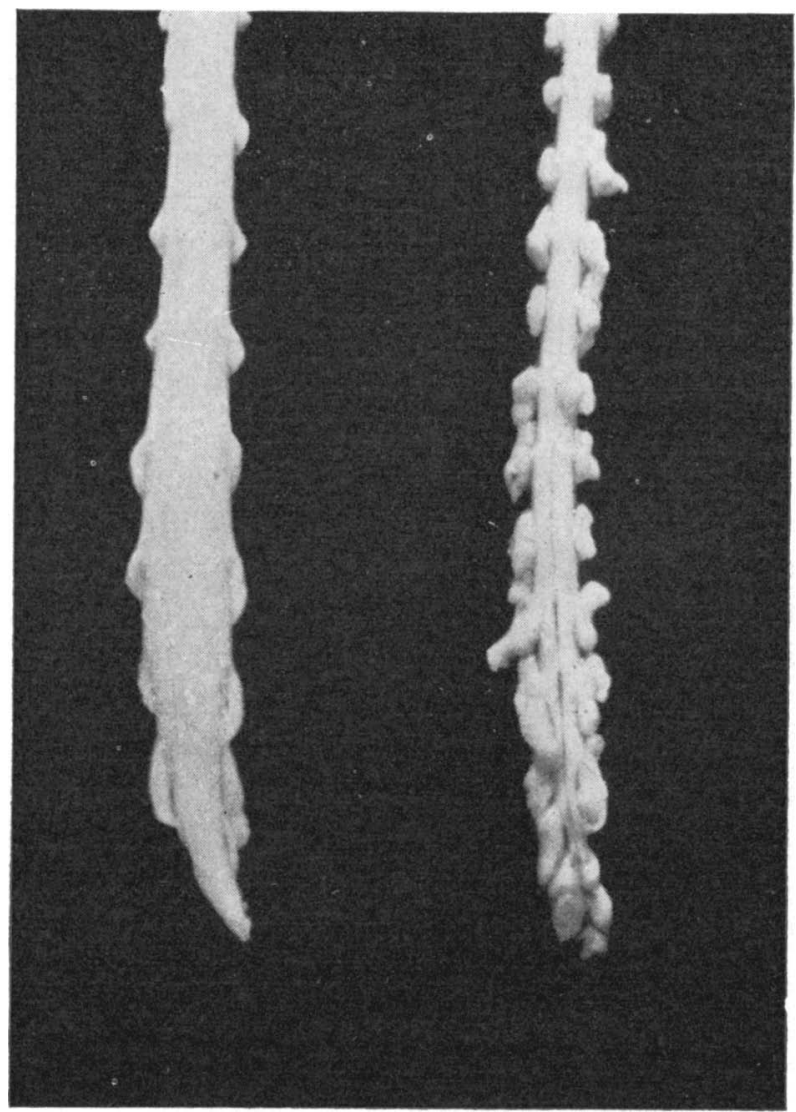

Fig. 1 3. The spinal cord from the same piglets as in fig. 12. Bilateral herniations of the spinal cord in pig no. 7II.

\section{DISCUSSION}

According to classification based on formal genesis, there are 3 groups of malformations: suppressive (hypoplasia and aplasia), excessive (hyperplasia) and erratic (paraplasia). All three groups are demonstrated in the present material, the first most fully. Among the pronounced excessive malformations can be mentioned "excessive ears" and polydactylism. Abnormal lobulation of the lungs, liver cysts, horse-shoe kidneys and hermaphroditism must be classified as erratic malformations.

In addition to "formel genesis", the question of "causal genesis" arises. Here, primarilly, it might seem that the malformations described were dependent on nutrition, heredity or infection. The diet given to the sows and gilts should be fully 
sufficient, aside from the vitamin A deficiency. By numerous liver biopsies and liver analyses of litter mates, control was kept of the vitamin $A$ status in the pigs used in the experiments.

The question of the extent to which a genetic factor affects results may be omitted as the female litter mates of the pigs used in the experiment farrowed normal litters of suckling piglets, and the boars used have produced normal litters with other sows. Neither macroscopic nor microscopic examination of the malformed suckling pigs showed any sign of infectious disease.

As mentioned earlier, gilts from litters 3, 4 and 7 were the only gilts used in the experiments which completed pregnancy without a supply of vitamin A. In Table 1 it appears that certain malformations, hypotrichosis, hydrocephalus and herniations of the spinal cord were only observed in these 3 litters, while other malformations such as heart and kidney anomalies were far more frequent in litters which had been given vitamin A dosage from 29 to 36 days after breeding. Wilson et al. (1953) using A deficient female rats investigated the effect of a single large dose of vitamin $A$ on different days (10-15 days) of pregnancy. They found that the earlier vitamin $A$ was given, the fewer the malformations in the offspring. They demonstrated also that not only the types of malformations, but also the relative number of different defects varied considerably, depending on the time when vitamin A therapy was practiced. This is in good agreement with the investigations presented here. However on the basis of our results it is quite impossible to draw conclusions as to the effect of vitamin A therapy at different periods during pregnancy, as the utilization of the vitamin in question depends on the way of administration (Hjarde et al., 1961), and in the present experimental series, vitamin $A$ was injected both in aqueous and in oily dispersion.

From the following discussion it will appear that the majority of the malformations described in the literature on the subject are found in the offspring of rats with vitamin A deficiency, while only a few are described as being due to fetal vitamin A deficiency in pigs. An example is the contracture of the forelegs observed in all the piglets of 5 litters, never described before in connection with vitamin A deficiency. These malformations may be due to the pronounced alterations demonstrated in the nerve trunks and the muscles of the limbs.

The varying heart defects were in many cases so severe, that 
they alone would preclude all viability of the new-born pigs. Wilson and Warkany (1949) have described in detail similar aortic-arch and cardiac anomalies in newborn rats whose mothers were kept on a vitamin A deficient diet. In pigs, heart defects have been mentioned earlier (Bendixen, 1944) in connection with vitamin A deficiency.

Malformations of the lungs however, seems only to have been described in rats (Wilson et al., 1953). It is characteristic that hypoplasia is most pronounced in the left lung which, in normal animals is found to be morphologically less differentiated than the right lung.

While defects in diaphragma in rats are also mentioned earlier (Andersen, 1941, 1949; Wilson et al., 1953), liver cysts seem not to have been demonstrated earlier in connection with vitamin $A$ deficiency.

The malformations of coecum and colon, here described, have not hitherto been demonstrated in pigs. However they should be considered an arrest of development, as the formation of the intestine in the malformed pigs often corresponds to a relatively early fetal stage of development of the normal pig (Lineback, 1916). Metaplasia present in mucous membrane of the intestines of a single pig should, in consideration of the size of the material investigated, be considered an additional abnormality not typically seen in connection with vitamin A deficiency.

Hale (1933) described displacement of the kidneys, i.e. failure of metanephros to ascend. This malformation seems not by any means to be caused by a mechanical hindrance of the cranial migration of the kidney but should rather be considered a fetal cessation of kidney and ureteric development. As mechanical hindrance has been mentioned that the umbilical artery dented the kidney and thus prevented its cranial migration. Only in a few cases in the present material was such a denting caused by the umbilical artery observed. However that condition with its sparse occurrence cannot be of any etiological importance in the question of kidney malplacement, it should rather be considered a secondary manifestation. The histological changes in the structure of the kidney also indicated delayed development. The dilatations of tubuli may possible be due to lacking differentiation of the medulla.

As already stated, malformations of the genital organs have been described (Bendixen, 1944) both in male and female pigs. 
Only in a single instance did true hermaphroditism occur, and must have been due to aberrant development. The other defects in the genital organs may have been caused by arrest of development and were more pronounced and important in the female pigs. The frequent aplasia or hypoplasia of the horns and body of uterus and cervix were thus very characteristic of the vitamin A deficient gilts. A similar condition in female rats is described in detail (Wilson and Warkany, 1948).

Ever since the discovery of vitamin A, replacement of various epithelia by stratified squamous keratinizing epithelium has been considered the most characteristic indication of A-avitaminosis. However such metaplasia have for the most part been described in growing, or fully grown, animals, only a few such changes have been demonstrated in newly born animals. Wilson and Warkany (1947) described keratinized metaplasia in older rat fetuses in that part of the uro-genital system which is derived from the uro-genital sinus. Goodwin and Jennings (1958) found proliferation and vacuolisation - but no metaplasia of the epithelia in lungs, pancreas, salivary glands, renal pelvis and cervix. As stated in the present investigations, metaplasia was found in uterus, urethra as well as in cervix and vagina in the new-born, vitamin A deficient piglets. It is possible that the fact that changes in epithelium were only found in these regions may be due to a special sensitivity to vitamin A deficiency in these epithelia.

Since Hale (1933) described microphthalmia in pigs born of vitamin A deficient sows, malformations in the eyes have been much used in veterinary practice as an indication of early fetal vitamin A deficiency. In this connection it must be remembered that congenital eye deformities may also be due to virus infection in the pregnant sow (Harding and Done, 1956). Microphthalmia in pigs and also in rats has been the object of much interest. Warkany and Schraffenberger $(1944,1946)$ in investigations of fetuses from vitamin A depleted rats followed the histological development of eye deformities throughout the last half of the gestation period. As A vitamin deficiency doubtless only cause abnormalities in development if it manifests itself during organogenesis, investigations on the development of the eye in normal and in $\mathrm{A}$ avitaminotic fetuses must begin already when the piglets are about 18 days old. Investigations of this nature are not yet described. 
As already stated, in litters 3, 4 and 7, cerebro-spinal malformations were observed in all the pigs, while macroscopically, the other pigs of the experiment showed a normal development of the central nervous system. This is possibly due to the fact that such malformations arise so late in the pregnancy that the vitamin A supply to the other gilts has prevented injury to the development of the central nervous system.

Hydrocephalus and protrusions of the spinal cord have not earlier been demonstrated in new-born pigs in connection with A avitaminosis but in rabbits (Millen et al., 1953, 1954) and in rats (Wolbach and Bessey, 1941).

How this hydrocephalus arises has been the subject of exhaustive discussions. Millen et al. (1954) believe that the malformation in rabbits has some relation to excessive production of cerebro-spinal fluid in the choroid plexuses, possibly in connection with a relative insufficiency of the cerebral aqueduct. Mellanby (1945) had earlier described compression of the brain in puppies which were kept on a vitamin $A$ free diet, and found that the cause in this case was thickening of the bones of the skull and consequent compression of the nervous tissue. However, it must be kept in mind that factors may vary in their influence on the appearance of a pathological condition depending among other causes, on the species of the animal, its age and its rate of growth. In the present experiment one cannot exclude the possibility that thickening of the bones at the base of the skull influenced the appearance and development of hydrocephalus even it has not yet been possible to prove it. While Millen et al. (1954) have thus emphasized the excessive production of cerbro-spinal fluid and Mellanby (1945) pointed out thickening in the bones of the skull, Wolbach and Bessey (1941) advanced the theory that the nervous tissue grew proportionately faster than the bone in vitamin A deficient rats. This resulted in compression of brain and spinal cord. These workers found by investigations of growing rats with signs of incoordination, compression and distortion of the brain dislocation towards foramen magnum with herniation of the cerebellum. In the spinal canal was similar overcrowding with distortion of the spinal cord and herniation of the nerve roots into the vertebral foramens and the vertebral bodies. According to description, these changes in the spinal cord in rats correspond to our observations in piglets, however, with the characteristic difference that the changes are 
complete in the newborn pigs, while Wolbach \& Bessey demonstrated such changes in young rats $6-9$ weeks after weaning.

Congenital malformations may as in the present investigations be due to nutritient deficiencies but can also be caused by factors of physical, chemical, infectious or genetic nature (Giroud, 1955; Kalter and Warkany, 1959). The question then arises: To what extent are the malformations just described specific for vitamin A deficiency? A series of experiments the majority of which were made with rats shows that also deficiency of other essential nutrients as p. ex. riboflavin (Nelson et al., 1956), pantothenic acid (Boisselot, 1949), vitamin $B_{12}$ and folic acid (Overholser et al., 1954) may be the cause of disturbances in organogenesis resulting in malformations of similar nature as here described. Microphthalmia has also been induced experimentally in rats in connection with A hypervitaminosis (Cohlan, 1954, Giroud and Martinet, 1955). Oxygen deficiency of the fetuses may cause disturbances in the development of the central nervous system (Mushett, 1953) and of the heart and the eye (Rübsaamen and Schellong, 1953; Werthemann and Reiniger, 1950). Eye defects in form of "retinal rosettes" have been observed in connection with abortus provocatus by X-ray application (Lindenfeld, 1913) and later experimentally induced in rabbit embryos by X-ray irradiation of the abdomen of pregnant rabbits (Pagenstecher, 1916). In connection with the infections may be mentioned that inoculation of a pregnant sow with an attenuated strain of swine fever virus caused $f$. inst. microphthalmia and cleft palate in the piglets (Harding and Done, 1956).

Malformations in pigs such as microphthalmia, cleft palate, limb contraction, hydrocephalus, hermaphroditismus and diaphragmatic hernia has all been described as hereditary of origin (Koch, Fischer and Schumann, 1957). In this connection should be mentioned that genetic factors to a certain extent may influence the teratogenic effect of malnutrition. It has been found by use of a strain of rats genetic predisposed for diaphragmatic hernia, that the frequency of this malformation in the offspring was greatly increased when the mothers was fed a vitamin A deficient diet (Andersen, 1941, 1949).

Of all the malformations found only one, malformation of the spinal cord, seems to be specific for A-avitaminosis. This condition may be due to the fact that the nerve tissue develops relatively normally in spite of the vitamin A defiency whiler the 
growth of bone tissue is retarded. The malformation may therefore be explained as a mechanical phenomenon and it only occurs in the litters of sows which have been vitamin A depleted during the last part of pregnancy.

The fact that so different pathophysiological conditions as p. ex. deficiency of vitamin A, riboflavin or oxygen early in fetal life may show practically similar teratogenic effect indicates, as also the investigation of Wilson et al. (1953), that the malformations primarily are due to disturbances in the active organogenesis. It indicates furthermore, that the biochemical mechanism through which the different deficiencies influence the organogenesis to at least some extent must be the same.

\section{ACKNOWLEDGEMENTS}

The author wishes to thank L. E. Lindegaard, V. D. M., for preparing the photographic material of this publication. Furthermore my thanks are due to Mrs. E. Velk for skilful help in carrying out the technical part of the histological work.

\section{REFERENCES}

Andersen, D. H.: Amer. J. Dis. Child. 1941, 61, 888.

Andersen, D. H.: Amer. J. Path. 1949, 25, 163.

Bendixen, H. C.: Act. path. microbiol. Scand. 1944, suppl. LIV, 161.

Boisselot, J.: Arch. franc. Pédiat. 1949, 6, 225.

Cohlan, S. Q.: Pediatrics 1954, 13, 556.

Giroud, A. \& Martinet, M.: Arch. franc. Pédiat. 1955, 12, 292.

Giroud, A.: Biol. Méd. 1955, 44, 524.

Goodwin, R. F. W. \& Jennings, A. R.: J. comp. Path. 1958, 68, 82.

Hale, F.: J. Hered. 1933, 24, 105.

Hale, F.: Amer. J. Ophthalm. 1935, 18, 1087.

Harding, J. D. J. \& Done, J. F.: Vet. Rec. 1956, 68, 865.

Hjarde, W., Neimann-Sфrensen, A., Palludan, B. \& Havskov Sфrensen, $P$.: Act. agr. Scand. 1961, in print.

Kalter, H. \& Warkany, J.: Phys. Rev. 1959, 39, 69.

Koch, P., Fischer, H. \& Schumann, H.: Erbpathologie der landwirtschaftlichen Haustiere. Paul Parey 1957.

Lindenfeld, B.: Klin. Mbl. Augenheilk, 1913, 51, I, 440.

Lineback, P. E.: Amer. J. Anat. 1916, 20, 483.

Mellanby, E.: Proc. Royal Soc. London, Series B, 1945, 132, 28.

Millen, J. W., Woollam, D. H. M. \& Lamming, G. E.: Lancet 1953, 265, 1234.

Millen, J. W., Woollam, D. H. M. \& Lamming, G. E.: Lancet 1954, 267, 679.

Mushett, Ch. W.: Beitr. pathol. Anat. 1953, 113, 367. 
Nelson, M. M., Baird, C. D. C., Wright, H. V. \& Evans, H. M.: J. Nutr. $1956,58,125$.

Overholser, M. D., Whitley, J. R., O'Dell, B. L. \& Hogan, A. G.: Anat. Rec. 1954, 120, 917.

Pagenstecher, H. E.: Ber. ophthal. Ges. Heidelberg, 1916, 40, 447.

Rübsaamen, H. \& Schellong, G.: Rev. Path. Gén. Comp. 1953, 53, 1091.

Schoop, G.: Tierärtzl. Umsch. 1955, 10, 194.

Warkany, J. \& Schraffenberger, E.: Proc. Soc. Exp. Biol. Med. 1944, $57,49$.

Warkany, J. \& Schraffenberger, E.: Arch. Ophthal. 1946, 35, 150.

Werthemann, A. \& Reiniger, M.: Acta anat. 1950, 11, 329.

Wilson, J. G. \& Warkany, J.: Proc. Soc. Exp. Biol. Med. 1947, 64, 419.

Wilson, J. G. \& Warkany, J.: Amer. J. Anat. 1948, 83, 357.

Wilson, J. G. \& Warkany, J.: Amer. J. Anat. 1949, 85, 113.

Wilson, J. G., Roth, B. C. \& Warkany, J.: Amer. J. Anat. 1953, 92, 189.

Wolbach, S. B. \& Bessey, O. A.: Arch. Path. 1941, 32, 689.

\section{SUMMARY}

In connection with experiments concerning the utilization of perorally and parenterally administered vitamin $A$ in pigs and the transfer of this vitamin from the mother to the fetuses investigations were performed concerning the teratogenic effect of vitamin A deficiency in this animal.

9 sows and gilts which throughout the pregnancy or in the first third of this were depleted of vitamin A gave birth to 91 piglets all of which had malformations cf. Table 1 . The most frequent anomaly was microphthalmia; of other characteristic malformations may be mentioned heart defects, diaphragmatic hernia, malformed and not ascended kidneys, underdevelopment of genital organs, internal hydrocephalus and herniations of the spinal cord.

Of this syndrome of malformations only one, namely the herniations of the spinal cord, seems to be specific for vitamin A deficiency. This malformation may be due to retarded growth of the bone tissue in relation to the relative normal growth of the nerve tissue.

\section{ZUSAMMENFASSUNG}

Der teratogene Effekt des A-Vitaminmangels bei Schweinen.

Im Zusammenhang mit Versuchen über die Ausnutzung parenteral und peroral applizierten A-Vitamins bei Schweinen und die Uebertragung dieses Vitamins von der Muttersau auf den Fötus wurden Untersuchungen über den teratogenen Effekt des A-Vitaminmangels ausgeführt.

9 Säue, bei denen der A-Vitamingehalt während der ganzen Trächtigkeit oder im ersten Drittel derselben völlig erschöpft war, bekamen insgesamt 91 Ferkel, die durchweg Missbildungen aufwiesen; vergl. Tabelle 1. Die am häufigsten beobachtete Anomalie war Mikrophthal- 
mie. Von anderen charakteristischen Missbildungen können Herzdefekte, Diaphragmabruch, mangelhafte Aszendierung missgebildeter Nieren, Unterentwicklung der Geschlechtsorgane, interne Hydrocephalie und Rückenmarksprotrusionen genannt werden.

Der vergleichenden Litteratur gemäss scheint nur ein einziges von diesen Syndromen, nämlich die Rückenmarksprotrusionen, für den A-Vitaminmangel spezifisch zu sein. Diese Missbildung wird wahrscheinlich einem verspäteten Wachstum des Knochengewebes im Verhältnis zu dem relativ normalen Wachstum des Nervengewebes zugeschrieben.

\section{SAMMENDRAG}

Den teratogene effekt af A-vitaminmangel hos svin.

I forbindelse med fors $\emptyset \mathrm{g}$ over udnyttelsen af parenteralt og peroralt appliceret A-vitamin til svin samt overf $\phi$ rsel af dette vitamin fra so til fostre blev der foretaget unders $\varnothing$ gelser over A-vitaminmanglens teratogene effekt.

9 gylte og søer, der under hele drægtigheden eller i den første trediedel af denne, var fuldstændig udtømt for A-vitamin, fik ialt 91 grise, der alle udviste misdannelser, jvfr. tabel 1. Den hyppigst forekommende anomali var mikrophthalmi. Af andre karakteristiske misdannelser kan nævnes hjertedefekter, diafragmabrok, manglende ascendering af misdannede nyrer, underudvikling af kønsorganer samt intern hydrocephali og rygmarvsprotrusioner.

Efter den komparative litteratur at dømme synes kun en enkelt af dette syndrom af misdannelser, nemlig rygmarvsprotrusionerne, at være specifik for A-vitaminmanglen. Denne misdannelse skyldes sandsynligvis en forsinket vækst af knoglevævet $\mathrm{i}$ forhold til den relativt normale vækst af nervevævet.

(Received October 23. 1960). 